\title{
ANALISIS PENGARUH BAURAN PEMASARAN TERHADAP PENGAMBILAN KEPUTUSAN MENABUNG BRITAMA PADA PT BANK RAKYAT INDONESIA (PERSERO), TbK CABANG PEMBANTU PURI ANJASMORO SEMARANG
}

\author{
Kinanda Nor Cahya Ningtias *) \\ Embun Duriany Soemarso **)
}

\begin{abstract}
This study aims to determine the significance of marketing mix variables consisting of product, price, promotion, place, people, processe, and physical evidence of BritAma saving decision making at PT Bank Rakyat Indonesia (Persero), Branch of Puri Anjasmoro Semarang.

This study uses primary data from the distribution of questionnaires and secondary data from book literature and research journals. The population of this research is all the savings customers of BritAma PT Bank Rakyat Indonesia (Persero), Tbk Branch of Puri Anjasmoro Semarng. Sampling technique in this research is purposive sampling and accidental sampling. Data analysis method in this research is Multiple Linear Regression Analysis Model. Besides, data quality test in this research is done by using validity test and reliability test, and classical assumption test in the form of normality test, heteroskedasticity test, and multicolonierity test. In this study used data analysis techniques in the form of $F$ test, $t$ test, and coefficient of determination (R2).

Based on the results of the analysis and discussion shows that the product, price, promotion, place, person, process, and physical evidence simultaneously significantly influence the decision of saving BritAma at PT Bank Rakyat Indonesia (Persero), Tbk Branch of Puri Anjasmoro Semarang. While partially there are only four variables that have a significant effect on Britama saving decision making is the product, promotion, place, and process. For the other three variables are price, people, and physical evidence have no significant effect on the decision of saving BritAma at PT Bank Rakyat Indonesia (Persero), Tbk Branch of Puri Anjasmoro Semarang.
\end{abstract}

Keywords : Marketing Mix, Product, Price, Promotion, Place, People, Process, Physical Evidence, and Savings Decision.

*) Mahasiswa Tugas Akhir Prodi Keuangan dan Perbankan, Jurusan Akuntansi, Politeknik Negeri Semarang

**) Dosen Jurusan Akuntansi, Politeknik Negeri Semarang

\section{PENDAHULUAN}

\section{Latar Belakang Masalah}

Dewasa ini negara kita sedang giat-giatnya melaksanakan pembangunan di berbagai sektor. Salah satunya yaitu di sektor perbankan. Menurut Undang-Undang Republik Indonesia Nomor 10 Tahun 1998 tentang Perbankan pasal 1 ayat 1 menyatakan bahwa, Perbankan adalah segala sesuatu yang menyangkut tentang bank, mencakup kelembagaan, kegiatan usaha, serta cara dan proses dalam melaksanakan kegiatan usahanya. 
Bank mempunyai tugas utama sebagai penghimpun dana (dana simpanan) masyarakat yang berupa giro, deposito dan tabungan, serta menyalurkan dana yang telah terhimpun dalam bentuk kredit. Dari ketiga jenis simpanan, tabungan merupakan jenis yang lebih banyak ditawarkan oleh bank.

Saat ini dalam industri sektor perbankan sendiri terjadi persaingan pada setiap aspek operasionalnya, baik dalam rangka pemupukan dana dari masyarakat maupun penyaluran dana yang dihimpun tersebut. Dalam menghadapi persaingan tersebut setiap bank harus mampu menunjukkan berbagai kelebihan serta keunggulan tertentu dari para pesaingnya, agar dapat menarik minat masyarakat untuk selalu berhubungan dengannya.

Persaingan dalam dunia perbankan, tentunya berkaitan dengan menarik minat nasabah terhadap produk yang ditawarkan dan bagaimana cara bank untuk dapat membuat nasabah mengambil keputusan pembelian terhadap produk yang ditawarkannya. Pengambilan keputusan merupakan perilaku keputusan konsumen terhadap produk dan jasa sebagai hasil hubungan yang saling mempengaruhi antara faktor-faktor budaya, sosial, keluarga, situasi, individu dan faktor psikologis, (Sari, 2015).

Salah satu cara yang dapat dilakukan Bank untuk menarik minat nasabah sehingga mempengaruhi nasabah untuk mengambil keputusan pembelian terhadap produk yang ditawarkan yaitu dengan berusaha untuk memenuhi keinginan dan kebutuhan nasabah. Dalam pemenuhan keinginan dan kebutuhan nasabah membutuhkan konsep pemasaran yang disebut dengan bauran pemasaran (merketing mix). Kotler dan Amstrong (2001:73) mendefinisikan bauran pemasaran sebagai seperangkat alat pemasaran taktis dan terkontrol yang dipadukan oleh perusahaan untuk menghasilkan respon yang diinginkan pasar sasaran . Kemungkinan-kemungkinan itu dapat dikelompokkan menjadi 4 (empat) variabel yang dikenal dengan "Empat P" antara lain product, price, place, dan promotion (produk, harga, distribusi, dan promosi). Dalam perkembangannya, pengembangan bauran pemasaran jasa menjadi semakin meluas. Menurut Yazid (2005:18) bahwa ada penambahan dari 4P yang sudah ada menjadi 7P dengan penambahan people (orang), physical evidence (bukti fisik atau lingkungan fisik dimana jasa diberikan), dan process (proses).

Di Indonesia terdapat beberapa bank terbesar yang saling bersaing untuk menarik perhatian dan minat nasabah terhadap produknya masing-masing. Salah satunya yaitu PT Bank Rakyat Indonesia (Persero), Tbk atau biasa disebut Bank BRI. Dalam menjalankan kegiatan usahanya, seluruh unit kerja operasional Bank BRI di seluruh wilayah Indonesia termasuk di dalamnya PT 
Bank Rakyat Indonesia (Persero), Tbk Cabang Pembantu Puri Anjasmoro Semarang memerlukan langkah yang tepat untuk menarik perhatian dan minat nasabah untuk melakukan pembelian terhadap produk simpanan yang ditawarkan dalam hal ini yaitu tabungan dengan cara menerapkan konsep bauran pemasaran yang tepat untuk mempromosikan produk tabungan yang ditawarkan.

Bank BRI mempunyai berbagai macam produk tabungan salah satunya yaitu tabungan BRI BritAma. Berikut ini terdapat data kategori produk tabungan yang masuk ke dalam Top Brand Award yang dapat dilihat pada Tabel 1 dibawah ini :

Tabel 1

Daftar Tabungan Kategori Banking and Finance Top Brand A ward Tahun 2014-2017

\begin{tabular}{|c|l|c|c|c|c|c|}
\hline \multirow{2}{*}{ No } & \multirow{2}{*}{ Merek Tabungan } & \multicolumn{4}{|c|}{ TBI } & \multirow{2}{*}{ TOP } \\
\cline { 3 - 6 } & & 2014 & 2015 & 2016 & 2017 & \\
\hline 1. & Tahapan BCA & $29,4 \%$ & $29,1 \%$ & $24,4 \%$ & $25,0 \%$ & TOP \\
\hline 2. & BRI Simpedes & $11,1 \%$ & $10,5 \%$ & $16,6 \%$ & $15,5 \%$ & TOP \\
\hline 3. & BRI BritAma & $\mathbf{1 9 , 9 \%}$ & $\mathbf{1 7 , 0 \%}$ & $\mathbf{1 5 , 1 \%}$ & $\mathbf{1 3 , 2 \%}$ & TOP \\
\hline 4. & BNI Taplus & $9,6 \%$ & $10,4 \%$ & $10,2 \%$ & $9,2 \%$ & \\
\hline 5. & Tabungan Mandiri & $17,5 \%$ & $14,6 \%$ & $7,4 \%$ & $7,6 \%$ & \\
\hline
\end{tabular}

Sumber : Top Brand Award.com

Berdasarkan Tabel 1 yang telah diuraikan di atas, terlihat bahwa Top Brand Index (TBI) tabungan BRI BritAma mengalami penurunan selama 3 tahun berturut-turut. Selain itu di tahun 2016 BRI BritAma juga mengalami penurunan peringkat, yang awalnya di tahun 2015 menduduki peringkat kedua dan di tahun 2016 BRI BritAma berada di peringkat ketiga. Hal ini menunjukkan bahwa merek tabungan BRI BritAma dari Bank BRI memiliki citra merek yang semakin menurun terhadap persepsi para nasabah. Sehingga hal tersebut dapat mengakibatkan minat beli terhadap tabungan BRI BritAma juka akan mengalami penurunan. Masalah ini harus segera di perbaiki oleh Bank BRI dengan menerapkan strategi pemasaran yang lebih kuat dan tepat agar para nasabah lebih tertarik dengan tabungan BRI BritAma yang ditawarkan oleh Bank BRI.

\section{Rumusan Masalah}

Berdasarkan uraian kondisi yang terjadi di Bank BRI, maka permasalahan yang diangkat dalam penelitian ini yaitu bagaimana cara meningkatkan pengambilan keputusan menabung BritAma dengan pendekatan bauran pemasaran yang terdiri dari produk, harga, promosi, tempat, orang, proses, dan bukti fisik khususnya di Bank BRI Cabang Pembantu Puri Anjasmoro Semarang, sehingga diharapkan peringkat tabungan dapat naik dan citra tabungan BritAma dapat mengalami peningkatan peringkat dari tahun ke tahun. 


\section{KAJIAN TEORI}

\section{Bauran Pemasaran (Marketing Mix)}

Menurut Kotler dan Amstrong (2001:73) mendefinisikan bauran pemasaran sebagai seperangkat alat pemasaran taktis dan terkontrol yang dipadukan oleh perusahaan untuk menghasilkan respon yang diinginkan pasar sasaran . Bauran pemasaran terdiri atas segala sesuatu yang dapat dilakukan perusahaan untuk mempengaruhi permintaan produknya. Kemungkinankemungkinan itu dapat dikelompokkan menjadi 4 (empat) variabel yang dikenal dengan "Empat P" antara lain product, price, place, dan promotion (produk, harga, distribusi, dan promosi). Dalam perkembangannya, pengembangan bauran pemasaran jasa menjadi semakin meluas. Menurut Yazid (2005:18) bahwa ada penambahan dari 4P yang sudah ada menjadi 7P dengan penambahan people (orang), physical evidence (bukti fisik atau lingkungan fisik dimana jasa diberikan), dan process (proses).

Sedangkan menurut Lupiyoadi dan Hamdani (2006:70) menyatakan bahwa bauran pemasaran (marketing mix) merupakan alat bagi pemasar yang terdiri dari berbagai unsur suatu program pemasaran yang perlu dipertimbangkan agar implementasi strategi pemasaran dan positioning yang ditetapkan dapat berjalan sukses. Bauran pemasaran pada produk barang berbeda dengan bauran pemasaran untuk produk jasa. Bauran pemasaran produk barang mencakup 4P yaitu product, price, place, and promotion. Sedangkan untuk jasa, keempat hal tersebut masih dirasa kurang mencukupi. Para ahli pemasaran menambahkan tiga unsur lagi antara lain people, process, dan customer service. Perbedaan antara Lupiyoadi dan Hamdani dengan pendapat ahli sebelumnya ada pada customer service yang tidak ada dalam pendapat ahli sebelumnya. Penulis berpendapat bahwa customer service yang ada pada pendapat Lupiyoadi dan Hamdani sudah termasuk pada people yang disebutkan oleh para ahli sebelumnya. Sehingga penulis menggunakan unsur-unsur 7P yang terdiri dari product (produk), price (harga), promotion (promosi), place (tempat), people (orang), process (proses), dan physical evidence (bukti fisik). 


\section{Proses Pengambilan Keputusan}

Perusahaan yang cerdas berusaha untuk memahami proses keputusan pembelian pelanggan secara penuh, semua pelanggan mereka dalam pembelajaran, memilih, menggunakan, dan bahkan menyingkirkan produk.

Menurut Kotler dan Keller (2008:6), proses pemasaran telah mengembangkan "model tingkat" proses keputusan pembelian konsumen melalui lima tahap yaitu pengenalan masalah, pencarian informasi, evaluasi alternatif, keputusan pembelian, dan perilaku pasca pembelian. Proses pembelian dimulai jauh sebelum pembelian aktual dan mempunyai konsekuensi dalam waktu lama setelahnya.

\section{Penelitian Terdahulu}

Menurut Penelitian yang dilakukan oleh Fajri, dkk (2013), Tiwow (2013), Gusnawati (2014), Sari (2015), dan Antika, dkk (2017) menyatakan bahwa variabel produk (product) berpengaruh dignifikan terhadap keputusan nasabah untuk menabung. Adapun dari sisi variabel harga (price) yang berpengaruh signifikan terhadap keputusan menabung yaitu hasil penelitian dari Kurniato (2013), Octaviani (2016), dan Antika, dkk (2017). Selanjutnya terdapat hasil penelitian yang dilakukan oleh Tiwow (2013), Sari (2015), Octaviani (2016), dan Antika, dkk (2017) menyatakan bahwa variabel promosi (promotion) mempunyai pengaruh yang signifikan terhadap keputusan nasabah menabung. Sedangkan dari sisi variabel tempat (place) dan orang (people) yang menyatakan terdapat pengaruh yang signifikan terhadap keputusan nasabah menabung yaitu hasil penelitian dari Kurniato (2013), Tiwow (2013), Gusnawati (2014), Octaviani (2016), dan Antika, dkk (2017). Kemudian dari sisi variabel proses (process) yang menyatakan terdapat pengaruh yang signifikan terhadap keputusan nasabah menabung yaitu hasil penelitian yang dilakukan oleh Fajri, dkk (2013), Kurniato (2013), Sari (2015), Octaviani (2016), dan Antika, dkk (2017). Dan yang terakhir yaitu hasil penelitian dari Kurniato (2013), Tiwow (2013), Gusnawati (2014), dan Antika, dkk (2017) menyatakan bahwa bukti fisik (physical evidence) berpengaruh signifikan terhadap keputusan nasabah menabung.

\section{Kerangka Pemikiran Teoritis}

Berdasarkan kajian teoritis dan penelitian terdahulu yang telah diuraikan diatas, maka dalam penelitian ini variabel yang akan diteliti yaitu faktor bauran pemasaran (marketing mix) yang meliputi variabel produk (product), harga (price), promosi (promotion), tempat (place), orang (people), proses (process), dan bukti fisik (physical evidence) masing-masing memiliki pengaruh 
terhadap keputusan nasabah untuk menabung. Berdasarkan uraian dan penjelasan di atas, maka secara sederhana kerangka pemikiran teoritis dalam penelitian ini seperti pada Gambar 1 dibawah ini :

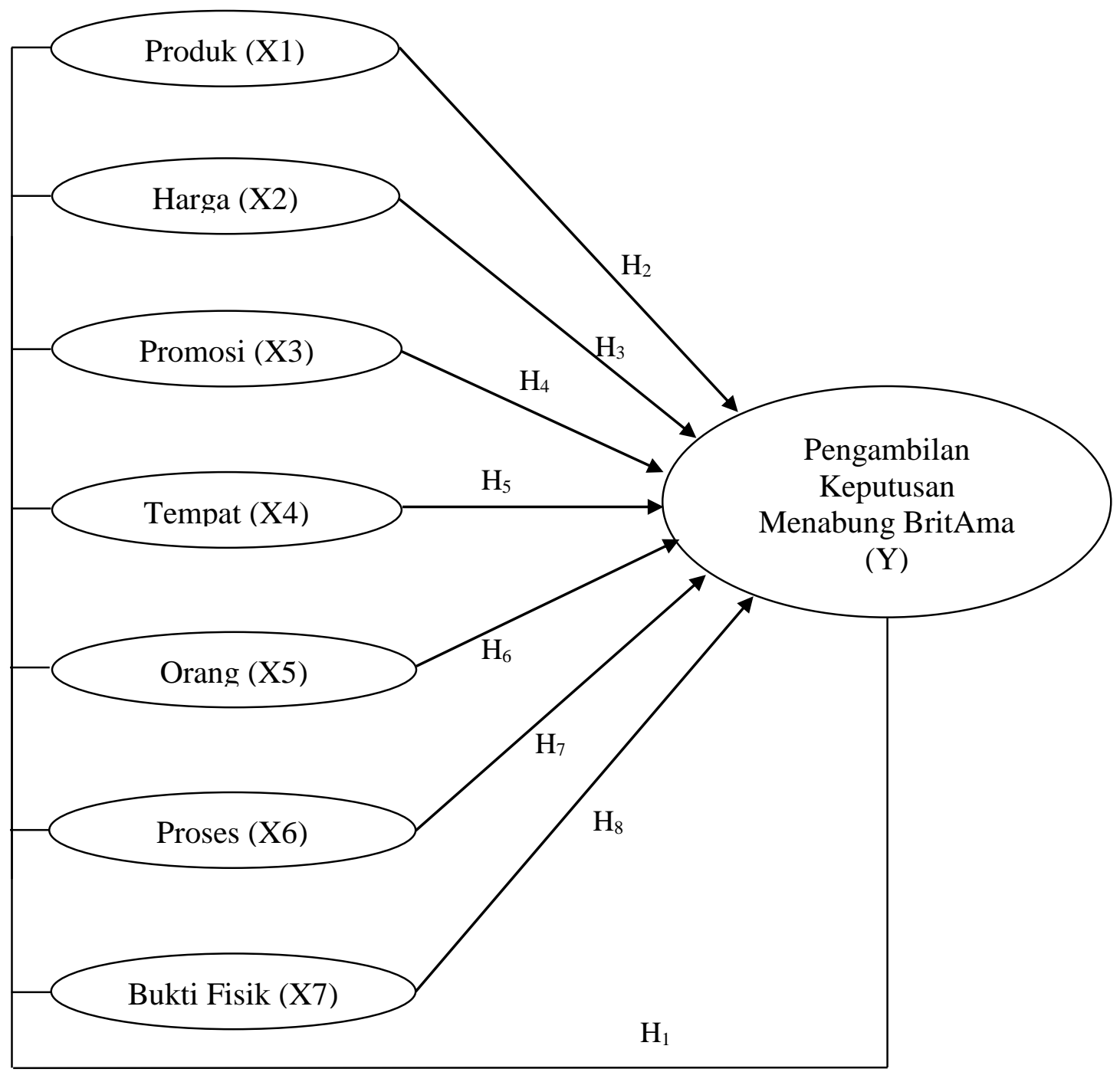

Gambar 1

Kerangka Pemikiran Teoritis

Sumber : Dikembangkan dari beberapa penelitian terdahulu dari Fajri, dkk (2013), Kurniato (2013), Tiwow (2013), Gusnawati, dkk (2014), Sari (2015), Octaviani (2016), dan Antika, dkk (2017) 


\section{METODE}

\section{Populasi dan Sampel}

Dalam penelitian ini, populasi yang digunakan adalah seluruh nasabah tabungan BritAma PT Bank Rakyat Indonesia (Persero), Tbk Cabang Pembantu Puri Anjasmoro Semaranag sebanyak 2.448 orang. Kemudian untuk sampel dalam penelitian ini menggunakan teknik Nonprobability Sampling yang terdiri dari Accidental Sampling dan Purposive Sampling, serta perhitungan sampel menggunakan rumus slovin sehingga didapatkan sampel sebanyak 100 nasabah (responden).

\section{Prosedur Pengumpulan dan Jenis Data}

Responden yang dituju dalam penelitian ini yaitu seluruh nasabah tabungan BritAma dan nasabah tabungan yang aktif melakukan transaksi, terdiri dari pengguna produk tabungan BritAma di PT Bank Rakyat Indonesia (Persero), Tbk Cabang Pembantu Puri Anjasmoro Semarang yang mudah dijumpai (diakses), serta memenuhi kriteria yang telah ditentukan sebelumnya oleh peneliti. Kemudian responden tersebut diminta untuk membantu pengisian kuesioner penelitian yang telah dibuat oleh peneliti terkait dengan keputusan menabung BritAma.

Jenis data dalam penelitian ini adalah data primer yang diperoleh dari jawaban responden nasabah tabungan BritAma PT Bank Rakyat Indonesia (Persero), Tbk Cabang Pembantu Puri Anjasmoro Semarang tentang keputusan menabung BritAma.

\section{HASIL DAN PEMBAHASAN}

\section{Uji Validitas dan Reliabilitas}

Uji Validitas digunakan untuk mengukur sah atau valid tidaknya suatu kuesioner, (Ghozali, 2009:49). Hasil dari penelitian ini menunjukkan bahwa semua indokator pada masing-masing variabel memiliki nilai $r_{\text {hitung }}>r_{\text {tabel }}$ dan nilai signifikansi $<0,05(0,000)$. Sehingga dapat disimpulkan bahwa masing-masing indikator yang digunakan dalam penelitian ini dinyatakan valid.

Uji reliabilitas digunakan untuk mengukur suatu kuesioner yang merupakan indikator dari variabel konstruk, (Ghozali, 2009:46). Hasil dari penelitian ini menunjukkan bahwa masingmasing variabel atau konstruk mempunyai nilai Cronbach Alpha >0,60. Sehingga dapat disimpulkan bahwa dalam penelitian ini masing-masing variabel atau konstruk (alat ukur) reliabel. 


\section{Uji Asumsi Klasik}

Uji normalitas bertujuan untuk menguji apakah dalam model regresi, variabel pengganggu atau residual memiliki ditribusi normal, (Ghozali, 2009:147). Hasil dari penelitian ini menunjukkan bahwa dari pengujian Kolmogorov-Smirnov menghasilkan nilai K-S sebesar 0,475 dengan nilai Asymptotic Significance yaitu sebesar 0,978 (>0,05). sehingga dapat disimpulkan bahwa dalam penelitian ini model regresi memenuhi asumsi normalitas.

Uji multikolonieritas bertujuan untuk menguji apakah model regresi ditemukan adanya korelasi diantara variabel bebas (independen), (Ghozali, 2009:95). Hasil penelitian ini menunjukkan bahwa masing-masing variabel bebas dalam model regresi mempunyai nilai Tolerance $>0,10$ dan VIF $<10$. Sehingga dapat disimpulkan bahwa dalam model regresi tidak ditemukan adanya korelasi diantara variabel bebas atau tidak terjadi multikolonieritas.

Uji heteroskedastisitas bertujuan untuk menguji apakah dalam sebuah model regresi terjadi ketidaksamaan varian dari residual satu pengamatan ke pengamatan yang lain, (Ghozali, 2009:125). Dari hasil uji glejser yang telah dilakukan menunjukkan bahwa dalam penelitian ini nilai probabilitas signifikansi dari masing-masing variabel dalam model regresi lebih besar dari 0,05 (5\%). Dengan demikian dapat dikatakan bahwa model regresi dalam penelitian ini tidak mengandung adanya heteroskedastisitas.

\section{Analisis Regresi Linier Berganda}

Analisis regresi bertujuan untuk mengukur kekuatan hubungan antara dua variabel atau lebih, selain itu analisis regresi juga menunjukkan arah hubungan antara variabel dependen dengan variabel independen, (Ghozali, 2009:86). Metode analisis regresi yang digunakan dalam penelitian ini adalah analisis regresi linier berganda. Hasil uji analisis regresi linier berganda dalam penelitian ini dirumuskan sebagai berikut :

$$
\begin{gathered}
\mathrm{Y}=\mathbf{2 , 2 0 4}+\mathbf{0 , 4 2 2}(\text { produk })+\mathbf{0 , 0 4 3}(\text { harga })+0,304(\text { promosi })+0,232 \\
\quad(\text { tempat })+\mathbf{0 , 1 6 3}(\text { orang })+\mathbf{0 , 5 6 3}(\text { proses })+\mathbf{0 , 0 6 5}(\text { bukti fisik })+\mathrm{e}
\end{gathered}
$$

\section{Uji Hipotesis}

Hipotesis 1, diduga bahwa variabel produk (product), harga (price), promosi (promotion), tempat (place), orang (people), proses (process), dan bukti fisik (physical evidence) secara simultan berpengaruh signifikan terhadap pengambilan keputusan menabung BritAma pada PT 
Bank Rakyat Indonesia (Persero) Tbk, Cabang Pembantu Puri Anjasmoro Semarang. Berdasarkan

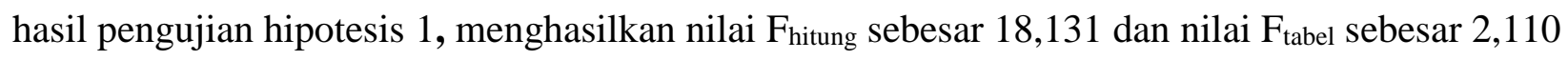
$\left(F_{\text {hitung }}>\mathrm{F}_{\text {tabel }}\right)$ dengan nilai signifikansi sebesar $0,000(<0,05)$. Sehingga hipotesis 1 diterima artinya variabel bauran pemasaran secara simultan berpengaruh signifikan terhadap pengambilan keputusan menabung BritAma. Hal ini didukung dengan penelitian yang dilakukan oleh Fajri, dkk (2013), Kurniato (2013), Tiwow (2013), Gusnawati, dkk (2014), Sari (2015), Octaviani (2016), dan Antika, dkk (2017) yang menyatakan bahwa variabel bauran pemasaran secara simultan berpengaruh signifikan terhadap keputusan nasabah untuk menabung.

Hipotesis 2, diduga bahwa variabel produk (product) secara parsial berpengaruh signifikan terhadap pengambilan keputusan menabung BritAma pada PT Bank Rakyat Indonesia (Persero) Tbk, Cabang Pembantu Puri Anjasmoro Semarang. Berdasarkan hasil pengujian hipotesis 2,

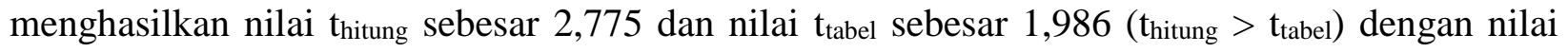
signifikansi sebesar 0,007 $(<0,05)$. Sehingga hipotesis 2 diterima artinya variabel produk secara parsial berpengaruh signifikan terhadap pengambilan keputusan menabung BritAma. Hasil penelitian ini sesuai dengan teori yang dikemukakan oleh Fajri, dkk (2013) yang menyatakan bahwa keberadaan produk harus dapat memenuhi kebutuhan konsumen, maka dalam hal ini manfaat yang diperoleh konsumen dari produk sangatlah penting, sehingga produk merupakan salah satu faktor penting bagi konsumen untuk memutuskan melakukan pembelian.

Hipotesis 3, diduga bahwa variabel harga (price) secara parsial berpengaruh signifikan terhadap pengambilan keputusan menabung BritAma pada PT Bank Rakyat Indonesia (Persero) Tbk, Cabang Pembantu Puri Anjasmoro Semarang. Berdasarkan hasil pengujian hipotesis 3, menghasilkan nilai $t_{\text {hitung }}$ sebesar 0,415 dan nilai $t_{\text {tabel }}$ sebesar 1,986 ( $t_{\text {hitung }}<t_{\text {tabel }}$ ) dengan nilai signifikansi sebesar 0,679 (>0,05). Sehingga hipotesis 3 ditolak artinya variabel harga secara parsial berpengaruh tidak signifikan terhadap pengambilan keputusan menabung BritAma. Hasil penelitian ini tidak sesuai dengan teori yang dikemukakan oleh Antika (2017) yang menyatakan bahwa harga (price) merupakan suatu penentu dalam keberlangsungan pembelian suatu produk. Hal ini disebabkan karena sebagian besar nasabah tidak mempermasalahkan tinggi rendahnya harga tabungan BritAma karena nasabah lebih mementingkan keamanan dananya dibandingkan dengan harga produk tabungannya. Buktinya walaupun terjadi fluktuasi harga tabungan BritAma ataupun biaya administrasi yang lebih rendah dibandingkan bank lain, hal itu tidak menjadi faktor utama bagi nasabah untuk mengambil keputusan menabung BritAma. 
Hipotesis 4, diduga bahwa variabel promosi (promotion) secara parsial berpengaruh signifikan terhadap pengambilan keputusan menabung BritAma pada PT Bank Rakyat Indonesia (Persero) Tbk, Cabang Pembantu Puri Anjasmoro Semarang. Berdasarkan hasil pengujian hipotesis 4, menghasilkan nilai thitung sebesar 2,734 dan nilai $t_{\text {tabel }}$ sebesar 1,986 (thitung $>t_{\text {tabel }}$ ) dengan nilai signifikansi sebesar $0,008(<0,05)$. Sehingga hipotesis 4 diterima artinya variabel promosi secara parsial berpengaruh signifikan terhadap pengambilan keputusan menabung BritAma. Hasil penelitian ini sesuai dengan teori yang dikemukakan oleh Antika, dkk (2017) yang menyatakan bahwa tanpa adanya promosi yang dijalankan oleh pihak perusahaan untuk memperkenalkan produknya, maka nasabah tidak mengetahui dan mengenal suatu produk yang dipasarkan oleh perusahaan, sehingga nasabahtidak akan mengambil keputusan untuk membeli.

Hipotesis 5, diduga bahwa variabel tempat (place) secara parsial berpengaruh signifikan terhadap pengambilan keputusan menabung BritAma pada PT Bank Rakyat Indonesia (Persero) Tbk, Cabang Pembantu Puri Anjasmoro Semarang. Berdasarkan hasil pengujian hipotesis 5, menghasilkan nilai $t_{\text {hitung }}$ sebesar 2,260 dan nilai $t_{\text {tabel }}$ sebesar 1,986 ( $\left.t_{\text {hitung }}>t_{\text {tabel }}\right)$ dengan nilai signifikansi sebesar 0,026 $(<0,05)$. Sehingga hipotesis 5 diterima artinya variabel tempat secara parsial berpengaruh signifikan terhadap pengambilan keputusan menabung BritAma. Hasil penelitian ini sesuai dengan teori yang dikemukakan oleh Octaviani (2016) dalam penelitiannya yang menyatakan bahwa dengan penentuan lokasi yang strategis dan sesuai dengan keinginan nasabah akan terus meningkatkan jumlah nasabah yang menyimpan tabungannya di bank.

Hipotesis 6, diduga bahwa variabel orang (people) secara parsial berpengaruh signifikan terhadap pengambilan keputusan menabung BritAma pada PT Bank Rakyat Indonesia (Persero) Tbk, Cabang Pembantu Puri Anjasmoro Semarang. Berdasarkan hasil pengujian hipotesis 6, menghasilkan nilai $t_{\text {hitung }}$ sebesar 0,920 dan nilai $t_{\text {tabel }}$ sebesar 1,986 ( $t_{\text {hitung }}<t_{\text {tabel }}$ ) dengan nilai signifikansi sebesar 0,360 (>0,05). Sehingga hipotesis 6 ditolak artinya variabel orang secara parsial berpengaruh tidak signifikan terhadap pengambilan keputusan menabung BritAma. Hasil penelitian ini tidak sesuai dengan teori yang dikemukakan oleh Yazid (2005:19) dalam penelitian Octaviani (2016) yang menyatakan bahwa orang adalah semua pelaku yang memainkan sebagian penyajian jasa dan karenanya mempengaruhi presepsi pembeli. Hal ini diebabkan karena pada dasarnya standar corporate culture yang diterapkan di setiap bank untuk karyawan atau petugasnya itu sama. Sehingga nasabah sudah terbiasa dengan tata cara pelayanan yang dilakukan oleh petugas bank. 
Hipotesis 7, diduga bahwa variabel proses (process) secara parsial berpengaruh signifikan terhadap pengambilan keputusan menabung BritAma pada PT Bank Rakyat Indonesia (Persero) Tbk, Cabang Pembantu Puri Anjasmoro Semarang. Berdasarkan hasil pengujian hipotesis 7,

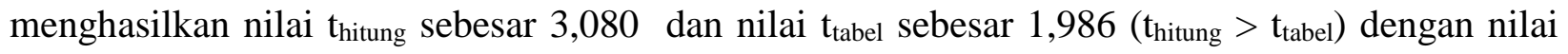
signifikansi sebesar 0,003 $(<0,05)$. Sehingga hipotesis 7 diterima artinya variabel proses secara parsial berpengaruh signifikan terhadap pengambilan keputusan menabung BritAma. Hasil penelitian ini sesuai dengan teori yang dikemukakan oleh Fajri, dkk (2013) yang menyatakan bahwa dalam perspektif perbankan, proses adalah alur dimana nasabah memulai membuka rekening tabungan sampai selesai melakukan transaksi dengan Bank, dengan demikian dapat diketahui proses memiliki signifikansi terhadap keputusan nasabah menabung.

Hipotesis 8, diduga bahwa variabel bukti fisik (physical evidence) secara parsial berpengaruh signifikan terhadap pengambilan keputusan menabung BritAma pada PT Bank Rakyat Indonesia (Persero) Tbk, Cabang Pembantu Puri Anjasmoro Semarang. Berdasarkan hasil pengujian hipotesis 8 , menghasilkan nilai $t_{\text {hitung }}$ sebesar 0,584 dan nilai $t_{\text {tabel }}$ sebesar 1,986 ( $_{\text {hitung }}<$ $\left.t_{\text {tabel}}\right)$ dengan nilai signifikansi sebesar 0,561 (>0,05). Sehingga hipotesis 8 ditolak artinya variabel bukti fisik secara parsial berpengaruh tidak signifikan terhadap pengambilan keputusan menabung BritAma. Hasil penelitian ini tidak sesuai dengan teori yang dikemukakan oleh Kotler (2008:18) dalam penelitian Sari (2015) yang menyatakan bahwa tampilan fisik yaitu unsur penting dalam bauran pemasaran untuk mengurangi tingkat resiko dengan jalan menawarkan bukti fisik dari karakteristik jasa, sehingga bukti fisik menjadi salah satu faktor penentu keputusan menabung bagi nasabah. Sama halnya dengan petugas bank, bukti fisik yang disediakan oleh Bank juga mempunyai standar tertentu yang harus diterapkan oleh setiap bank dan bukti fisik merupakan suatu kewajiban bagi Bank untuk dapat membuat nasabah merasa senang dan puas atas fasilitas yang diberikan, serta hal tersebut merupakan hak bagi nasabah.

\section{PENUTUP}

\section{Kesimpulan}

1. Variabel produk, harga, promosi, tempat, orang, proses, dan bukti fisik secara simultan berpengaruh signifikan terhadap pengambilan keputusan menabung BritAma pada PT Bank Rakyat Indonesia (Persero) Tbk, Cabang Pembantu Puri Anjasmoro Semarang. 
2. Variabel produk secara parsial berpengaruh signifikan terhadap pengambilan keputusan menabung BritAma pada PT Bank Rakyat Indonesia (Persero) Tbk, Cabang Pembantu Puri Anjasmoro Semarang.

3. Variabel harga secara parsial berpengaruh tidak signifikan terhadap pengambilan keputusan menabung BritAma pada PT Bank Rakyat Indonesia (Persero) Tbk, Cabang Pembantu Puri Anjasmoro Semarang.

4. Variabel promosi secara parsial berpengaruh signifikan terhadap pengambilan keputusan menabung BritAma pada PT Bank Rakyat Indonesia (Persero) Tbk, Cabang Pembantu Puri Anjasmoro Semarang.

5. Variabel tempat secara parsial berpengaruh signifikan terhadap pengambilan keputusan menabung BritAma pada PT Bank Rakyat Indonesia (Persero) Tbk, Cabang Pembantu Puri Anjasmoro Semarang.

6. Variabel orang secara parsial berpengaruh tidak signifikan terhadap pengambilan keputusan menabung BritAma pada PT Bank Rakyat Indonesia (Persero) Tbk, Cabang Pembantu Puri Anjasmoro Semarang.

7. Variabel proses secara parsial berpengaruh signifikan terhadap pengambilan keputusan menabung BritAma pada PT Bank Rakyat Indonesia (Persero) Tbk, Cabang Pembantu Puri Anjasmoro Semarang.

8. Variabel bukti fisik secara parsial berpengaruh tidak signifikan terhadap pengambilan keputusan menabung BritAma pada PT Bank Rakyat Indonesia (Persero) Tbk, Cabang Pembantu Puri Anjasmoro Semarang.

\section{Keterbatasan Penelitian}

1. Dalam penelitian ini, penulis hanya menggunakan variabel bauran pemasaran (marketing mix) yang terdiri dari produk (product), harga (price), promosi (promotion), tempat (place), orang (people), proses (process), dan bukti fisik (physical evidence).

2. Populasi yang diambil dalam penelitian ini hanya terbatas pada nasabah tabungan BbritAma PT Bank Rakyat Indonesia (Persero), Tbk Cabang Pembantu Puri Anjasmoro Semarang.

3. Pengambilan sampel dalam penelitian terbatas pada kriteria-kriteria tertentu yang telah ditetapkan oleh Penulis. 
4. Indikator-indikator yang digunakan dalam penelitian ini juga terbatas pada variabel yang digunakan oleh penulis dan hanya sebagian kecil indikator yang digunakan dalam kuesioner penelitian berkaitan dengan variabel yang diteliti.

5. Dalam penyelesaian penelitian ini, waktu yang digunakan oleh penulis relatif pendek dan dana yang dikeluarkan oleh penulis juga terbatas, sehingga penulis mengalami keterbatasan waktu dan dana dalam penelitian ini.

\section{Agenda Penelitian Mendatang}

1. Disarankan untuk peneliti selanjutnya agar dapat menambah variabel penelitian yang berkaitan dengan pengambilan keputusan nasabah untuk menabung seperti kualitas pelayanan dan lain sebagainya. Agar dalam penelitian tersebut mendapatkan lebih banyak kesimpulan mengenai faktor-faktor yang mempengaruhi keputusan nasabah untuk menabung.

2. Disarankan untuk penelitian selanjutnya, sebaiknya responden yang digunakan dalam penelitian ditambah lagi jumlahnya agar kuesioner dapat tersebar dengan maksimal di semua kalangan.

3. Indikator atau butir pertanyaan yang ada dalam kuesioner, sebaiknya ditambah lagi agar penelitian lebih mampu untuk menggambarkan keadaan yang sebenarnya di lapangan dan hasil yang diperoleh dapat maksimal.

4. Disarankan untuk peneliti selanjutnya, agar dapat menggunakan waktu dengan sebaik-baiknya dalam menyelesaikan penelitian dan mempersiapkan dana yang cukup agar penelitian dapat dilakukan dengan maksimal.

\section{DAFTAR PUSTAKA}

Antika et al. 2017. Pengaruh Marketing Mix Terhadap Keputusan Nasabah Untuk Menabung Di Tabungan Masyarakat Desa (Tamasa) Pada PT. BPR-LPN Sungai Rumbai Kabupaten Dharmasraya. Jurnal Ilmiah Mahasiswa STKIP PGRI Sumatera Barat.

Bank Indonesia. 1998. Undang-Undang Republik Indonesia No. 10 Tahun 1998 tentang Perbankan.

Fajri et al. 2013. Pengaruh Bauran Pemasaran Jasa Terhadap Keputusan Menabung (Survei Pada Nasabah Bank Muamalat Cabang Malang). Jurnal Administrasi Bisnis (JAB) | Vol. 6 No. 2 Desember 2013. 
Ghozali, Imam. 2009. Aplikasi Analisis Multivariate dengan Program IBM SPSS 19 Edisi 5. Semarang: Badan Penerbit Universitas Diponegoro.

Gusnawati et al. 2014. Pengaruh Marketing Mix Terhadap Keputusan Nasabah Untuk Menabung Simpedes Di PT. Bank Rakyat Indonesia (Persero), Tbk Cabang Batang Kapas Cabang Painan. e-Journal STKIP PGRI Sumatera Barat.

Hasan, Iqbal. 2010. Analisis Data Penelitian Dengan Statistik. Jakarta: PT Bumi Aksara.

Infobank. November 2017. Fastest Growing Companies 2017, 58-59.

Kotler, Philip dan Gary Armstrong. 2001. Prinsip - Prinsip Pemasaran Edisi Kedelapan Jilid 1. Jakarta: Erlangga.

Kotler, Philip dan Kevin Lane Keller. 2008. Manajemen Pemasaran Edisi Ketiga Belas Jilid 1. Jakarta: Erlangga.

Kurniato, Ernan. 2013. Pengaruh Marketing Mix Terhadap Keputusan Customer Menabung Di Taheta PT. Bank Pembangunan Daerah Kalimantan Tengah Cabang Tamiang Layang. Kindai Volume 9 Nomor 4, Oktober - Desember 2013.

Lupiyoadi, Rambat dan A. Hamdani. 2006. Manajemen Pemasaran Jasa. Jakarta: Salemba Empat. Octaviani, Margaretha Chistina. 2016. Pengaruh Buran Pemasran Jasa Terhadap Keputusan Nasabah Menabung Pada PT. Bank Mandiri (Persero) Di Surabaya. Artikel Ilmiah STIEP Surabaya, 2016.

Sari, Devi Kumala. 2015. Faktor-Faktor Bauran Pemasaran Jasa Yang Mempengaruhi Keputusan Nasabah Menabung Tabungan Prama Di Bankaltim Cabang Utama Samarinda. eJournal Ilmu Administrasi Bisnis, Volume 3, Nomor 1, 2015: 1-13.

Sugiyono. 2016. Statistika Untuk Penelitian. Bandung: Penerbit Alfabeta.

Sujarweni, Wiratna. 2015. SPSS untuk Penelitian. Yogyakarta: Penerbit Pustaka Baru Press.

Tiwow, Dewi Ayu Mayangsari. 2013. Pengaruh Marketing Mix Terhadap Keputusan Konsumen Untuk Menabung Pada Bank Perkreditan Rakyat (Studi Kasus PT. BPR Dana Raya Manado, Sulawesi Utara. e-Journal Unsrat 2013.

Wiyono, Gendro. 2011. Merancang Penelitian Bisnis dengan Alat Analisis SPSS 17.0 \& SmartPLS 2.0. Yogyakarta: Unit Penerbit dan Percetakan STIM YKPN.

http://bri.co.id/assets/pdf. (diakses pada tanggal 23 Desember 2017)

www.topbrand-award.com. (diakses pada tanggal 04 Desember 2017) 